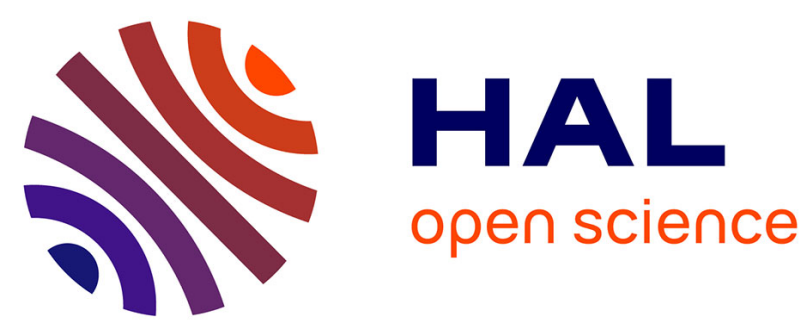

\title{
Study of Carbide Transformations during High-Temperature Oxidation of Nickel-Base Superalloys
}

\author{
P. Berthod, C. Vébert, L. Aranda, Renaud Podor, C. Rapin
}

\section{To cite this version:}

P. Berthod, C. Vébert, L. Aranda, Renaud Podor, C. Rapin. Study of Carbide Transformations during High-Temperature Oxidation of Nickel-Base Superalloys. Oxidation of Metals, 2005, 63 (1-2), pp.57-72. 10.1007/s11085-005-1951-6 . hal-02181301

\section{HAL Id: hal-02181301 https://hal.science/hal-02181301}

Submitted on 12 Jul 2019

HAL is a multi-disciplinary open access archive for the deposit and dissemination of scientific research documents, whether they are published or not. The documents may come from teaching and research institutions in France or abroad, or from public or private research centers.
L'archive ouverte pluridisciplinaire HAL, est destinée au dépôt et à la diffusion de documents scientifiques de niveau recherche, publiés ou non, émanant des établissements d'enseignement et de recherche français ou étrangers, des laboratoires publics ou privés. 


\title{
Study of the Carbide Transformations during High Temperature Oxidation of Nickel Base Superalloys
}

\author{
P. Berthod, C. Vébert, L. Aranda, R. Podor, and C. Rapin \\ Laboratoire de Chimie du Solide Minéral (UMR 7555), Université Henri Poincaré \\ BP 239, 54506 Vandoeuvre-lès-Nancy - France \\ E-mail : patrice.berthod@centraliens-lille.org
}

Microstructure phenomena resulting from high temperature oxidation of three nickel base superalloys were studied by microstructure examinations. Disappearance, nature modification, volume fraction evolution or precipitation of carbides were observed in the alloys near the external surface, depending on the temperature and the chemical composition of the alloys. Thermodynamic calculations allowed to better know what happened to carbon and to quantify its new distribution. The studied alloys lost a more or less great part of their sub-surface carbon content at $1200^{\circ} \mathrm{C}$ while carbon seemingly diffused deeper in the alloy at $1100^{\circ} \mathrm{C}$ and $1000^{\circ} \mathrm{C}$. The latter part of carbon promoted the coarsening of the pre-existing carbides, some modifications of their natures or the precipitation of new carbides in the matrix, then the occurrence of a new carbides zone.

KEY WORDS: Nickel alloys; Carbides; High temperature oxidation; Carbon; Thermodynamic calculations

Post-print version of the article Oxidation of Metals, Vol. 63, Nos. 1/2, pp. 57-72 (February 2005); DOI: 10.1007/s11085-005-1951-6

\section{INTRODUCTION}

During exposure to air at high temperature, the more reactive elements contained in a superalloy diffuse towards the oxidation front to be oxidized (Ref. 1). When temperature and/or time exposition are high enough, marked concentration gradients appear. This evolution of the local chemical composition can lead to microstructure modifications. Appearance of new phases, such as $\mathrm{Ni}$ austenite in $\alpha \mathrm{Cr}+\beta \mathrm{NiAl}$ alloys due to $\mathrm{Al}$ oxidation, or chromium carbides dissolution in Fe-Cr-C alloys, are two examples of such sub-surface microstructure changes which were already studied (Ref. 2). Fig. 1 illustrates, for example, the cases of several Ni-base superalloys strengthened by carbides, after exposure at different high temperatures for a long time. Their microstructures are modified by a disappearance of the initial carbides from the affected zone. A little deeper, it can be observed an obvious chemical modification of the initial carbides (become darker), a coarsening of the latter or a precipitation of new acicular phases. While it is generally easy to detect where metallic elements from disappearing phases have gone, it is much more difficult for other constitutive elements, like carbon, which are lighter or present in very smaller quantities. Such elements are not easy to analyze by microprobe and it is difficult to know what it happened to them. Fortunately, associated to the microstructure examinations, microanalysis of heavier elements, thermodynamic calculations can help to understand where light or rare elements have gone, then to better describe the oxidation phenomena or its consequences on the microstructure.

\section{EXPERIMENTAL METHOD}

\section{Chemical Composition of the Studied Alloys}

The alloys studied here are three simple nickel-base alloys, representing the base of more complex superalloys which are industrially employed in hot processes (Refs. 3-4). They all contain nickel, chromium, tantalum and carbon. Table I displays the chemical composition of the alloys. They were synthesized in small quantities by high frequency induction melting under argon gas (ingots of nearly $100 \mathrm{~g}$ ) in a copper cold crucible, in which they quickly solidified. 


\section{High Temperature Oxidation Exposures and Samples Preparation}

Oxidation tests at high temperatures were performed using a high temperature furnace under a dry industrial air flow $\left(80 \% \mathrm{~N}_{2}-20 \% \mathrm{O}_{2}\right.$ ) at 1.5 liter/hour (corresponding to a linear flow rate of about $5 \mathrm{~cm} / \mathrm{min}$ ). The samples were parallelepipeds (dimensions of about $2 \mathrm{~mm} \times 10 \mathrm{~mm} \times 10 \mathrm{~mm}$ ), the surface of which was polished with $\mathrm{SiC}$ paper from 80 to 1200 grid under water. Oxidation exposures were performed during 100 hours at $1000^{\circ} \mathrm{C}, 1100^{\circ} \mathrm{C}$ or $1200^{\circ} \mathrm{C}$. After oxidation tests all samples were covered using cathodic evaporation of gold, to give a good electrical conductivity to the external oxide layer, allowing thereafter a strengthening of the external oxide layer by an electrolytic deposition of nickel. The samples were cut in two parts using an Accutom-2 saw equipped with a diamond blade, then embedded in a cold resin (Araldite CY230 +Strengthener Escil HY956), and polished, first with SiC paper from 80 to 1200 grid under water, then finished with diamond pastes $6 \mu \mathrm{m}$ and $3 \mu \mathrm{m}$ (DP-Suspension P of Struers).

\section{Microstructure Examinations}

A Scanning Electron Microscope (SEM) Philips XL30 used in Back Scattered Electrons (BSE) mode allowed to clearly observe the constitutive phases since the average atomic numbers are sensibly different. In addition, some of them were clearly identified by Wavelength Dispersion Spectrometry (WDS) using a Cameca SX100 microprobe. Furthermore, SEM was also employed to analyze the mean chemical composition of a selected area over the local microstructure, except for carbon. Microprobe was also employed to get concentration profiles through the external zone deteriorated by oxidation.

\section{Image Analysis Measurements}

Measurements of the surface fractions of the different phases were realized on SEM photographs (BSE mode), using the AnalySIS software from Soft Imaging System GMBH which allows surface fractions measurements. Volume fractions were assessed from these results, assuming that surface fraction and volume fraction have similar values. Using room temperature densities of the different phases, the mass fraction of each phase was estimated thanks to the equation (1):

$$
\mathrm{f}_{\text {mass }}\left(\varphi_{\mathrm{j}}\right)=\frac{\rho_{\varphi_{\mathrm{j}}} \cdot \mathrm{f}_{\mathrm{vol}}\left(\varphi_{\mathrm{j}}\right)}{\sum_{\mathrm{i}}\left(\rho_{\varphi_{\mathrm{i}}} \cdot \mathrm{f}_{\mathrm{vol}}\left(\varphi_{\mathrm{i}}\right)\right)}
$$

where $\rho \varphi_{i}, f_{\text {mass }}\left(\varphi_{i}\right)$ and $f_{v o l}\left(\varphi_{i}\right)$ are respectively the density, the mass fraction and the volume fraction of the considered phase $\varphi_{i}$.

The densities values which were used (in $\mathrm{g} . \mathrm{cm}^{-3}$ ) are 8.9 for the matrix, 6.941 for the $\mathrm{Cr}_{7} \mathrm{C}_{3}$ carbide, 6.953 for the $\mathrm{Cr}_{23} \mathrm{C}_{6}$ carbide and 14.5 for the TaC carbide (Ref. 5).

\section{Thermodynamic Calculations}

Thermodynamic calculations were carried out using Thermo-Calc software (Ref. 6) with the SSOL database (SGTE) (Ref. 7), completed with binary and ternary systems (Ref. 8). Thermo-Calc calculations were performed for calculating isothermal and others diagrams for the oxidation zone first to determine an upper limit for the carbon content in the zone where carbides have disappeared. Second, it was also used to calculate the probable carbon content deeper in the alloy, knowing quantitatively both microstructure and the other elements contents from image analysis and microanalysis.

\section{RESULTS}

\section{Microstructure of the As-cast Alloys}

The alloys present a relatively fine structure which can be characterized by a space between two secondary dendrite arms of about $25 \mu \mathrm{m}$. The microstructure is constituted by an austenitic nickel matrix 
containing a part of the other elements and an interdendritic carbides network more or less dense depending on the carbon content (Fig. 2). These grain boundaries carbides are of different types, chromium carbides $\left(\mathrm{M}_{7} \mathrm{C}_{3}\right.$ and $\mathrm{M}_{23} \mathrm{C}_{6}$ ) and $\mathrm{TaC}$, for the three alloys. Indeed, WDS measurements (three per carbide for each alloy) showed that the three types of carbides coexist, what is not surprising since solidification and cooling were quicker than in a sand mold for example. Here the high temperature state has only partly evolved from the high temperature equilibrium.

\section{Observation of the Sub-surface Microstructure of the Alloys after Oxidation}

After high temperature oxidation for 100 hours, the bulk microstructures of the alloys are generally modified since they have converged to the equilibrium corresponding to both chemical composition and temperature. The three most visible microstructure modifications are the lost of the initial TaC carbides for Alloy A and Alloy B, a stoechiometry change of the chromium carbides for all alloys (rather $\mathrm{M}_{7} \mathrm{C}_{3}$ for the highest temperatures and rather $\mathrm{M}_{23} \mathrm{C}_{6}$ for the lowest ones) and a little increasing of the chromium carbides for Alloy A. All the samples are affected by both selective oxidation and internal oxidation that were analyzed by microprobe WDS measurements. The external oxide scale is mainly composed of $\mathrm{Cr}_{2} \mathrm{O}_{3}$, sometimes containing also rare little $\mathrm{CrTaO}_{4}$ inclusions. Internal oxides were clearly identified by microprobe WDS analysis as being $\mathrm{CrTaO}_{4}$, sometimes coexisting with voids. On the opposite no nitridation phenomena was observed. Under the external chromia layer the alloys present a more or less deep zone which was affected by oxidation and which may be composed of one or two different parts. The sub-surface microstructure state of Alloy A, Alloy B and Alloy C for all temperatures are respectively illustrated by Fig. 3, Fig. 4 and Fig. 5. From the external surface one always meets first a zone which lost all its initial carbides during oxidation. The thickness of this carbideless zone obviously depends on the temperature. For alloys tested at $1200^{\circ} \mathrm{C}$ this zone is directly followed by the bulk which presents an homogeneous microstructure. For alloys exposed to 1100 or $1000^{\circ} \mathrm{C}$, the carbideless zone and the bulk are separated by a second part of the affected zone. In that one the carbide system has undergone one or several types of modifications. The different carbides seen for each alloy and each temperature were analyzed by microprobe. This was often difficult because of the small size of the carbides, and sometimes it was possible that the results partly include the matrix present under the carbides. Table II shows the average values and the standard deviation values obtained with three or more results per type of carbide on each sample, to compare with the theoretic atomic $\mathrm{Cr} / \mathrm{C}$ ratio corresponding to the $\mathrm{M}_{7} \mathrm{C}_{3}$ and $\mathrm{M}_{23} \mathrm{C}_{6}$ stoechiometries. In some cases, the initial carbides have kept the same shape but their chemical composition has obviously changed since the carbides are here sensibly darker than everywhere else in the bulk (e.g. Alloy B at $1100^{\circ} \mathrm{C}$ in Fig. 4). In other cases, the carbides have kept their initial chemical composition but have grown during oxidation to finally give both a carbide surface fraction seemingly higher and lightly darker (SEM in BSE mode) because of the coarsened size of these carbides (e.g. Alloy C at $1000^{\circ} \mathrm{C}$ in Fig. 5). And sometimes at $1000^{\circ} \mathrm{C}$, new carbides appeared in the matrix with an acicular and oriented shape (e.g. Alloy A at $1000^{\circ} \mathrm{C}$ in Fig. 3). Such phenomena were seen and studied earlier for Ni-Cr-C alloys and cobalt-base superalloys (Ref. 9).

All the metallographic measures realized on both zone affected by oxidation and bulk for comparison, are resumed in Table III : the mean depth of the carbideless zone, the mean thickness of the zone where carbides are still here but modified (nature, surface fractions, new precipitation), the nature (determined by WDS micro-analysis) and the mean surface fraction of carbides in this latter zone. For comparison, the mean surface fraction of carbides in the bulk are also reminded. It appears that the depth of the carbideless zone increases with temperature for all the alloys (less than $50 \mu \mathrm{m}$ for $1000^{\circ} \mathrm{C}$ to about $200 \mu \mathrm{m}$ for $1200^{\circ} \mathrm{C}$ ) while the thickness of the intermediate zone where carbides are still here but modified (thereafter called "new carbides zone"), also increases with temperature from $1000^{\circ} \mathrm{C}$ to $1100^{\circ} \mathrm{C}$ to finally disappear at $1200^{\circ} \mathrm{C}$. Concerning the new carbides zone, it can be noted first that the total surface fraction of carbides is sensibly higher than in the bulk. Second, the microstructure changes between the bulk and this zone seemingly consist of a shifting from a mix of TaC+ $M_{23} C_{6}$ (bulk) to only $M_{23} C_{6}$ or to only $M_{7} C_{3}$, from a mix of $M_{23} C_{6}+M_{7} C_{3}$ to another mix of less $\mathrm{M}_{23} \mathrm{C}_{6}$ and more $\mathrm{M}_{7} \mathrm{C}_{3}$ or to only $\mathrm{M}_{7} \mathrm{C}_{3}$. Third, when temperature increases from $1000^{\circ} \mathrm{C}$ to $1100^{\circ} \mathrm{C}$, the nature of carbides in the new carbides zone shifts, from $\mathrm{M}_{23} \mathrm{C}_{6}$ to $\mathrm{M}_{7} \mathrm{C}_{3}$ or from $\mathrm{M}_{23} \mathrm{C}_{6}+\mathrm{M}_{7} \mathrm{C}_{3}$ to less $\mathrm{M}_{23} \mathrm{C}_{6}$ and more $\mathrm{M}_{7} \mathrm{C}_{3}$. 


\section{Thermodynamic Study of the Carbideless Zone}

The carbides initially present in this zone near the extreme surface have totally disappeared from the grain boundaries, where they are sometimes replaced by rare internal $\mathrm{CrTaO}_{4}$ oxides. It can be considered that only one phase is present here : the matrix. The total absence of carbides in this zone implies that carbon is probably become rare in this carbideless zone. Thermodynamic calculations were of a precious help to quantify the maximal carbon content possible in this zone taking into account the decrease of the chromium content through the carbideless zone. Fig. 6 shows for example the $1100^{\circ} \mathrm{C}$ isothermal phase diagram computed by Thermo-Calc for the Alloy A, a type of diagram which was already used earlier by Durham et al (Ref. 10) to describe the outwards diffusion path of carbon. In this example, WDS profiles having shown that the chromium content almost linearly decreases through the carbideless zone (from about $30 \%$ wt $\mathrm{Cr}$ to about $23 \%$ wt $\mathrm{Cr}$ ), the carbon solubility increases from $0.017 \%$ wt to $0.035 \%$ wt. Then the maximal possible carbon content can represent at the most $20 \%$ of the initial carbon content, and that only near the extreme surface.

Such results were obtained for the carbideless zones of all the alloys and all temperatures : it appeared that, in a first approximation, the carbon content in this zone can be considered as negligible compared to the initial one or in other zones having conserved or reached a significant amount of carbides.

\section{Thermodynamic Study of the New Carbides Zone}

The microstructure changes previously noted must be related to local modifications of the chemical composition of the alloy, due to the diffusion of its constitutive elements towards others locations. EDS and WDS microanalysis did not show sensible changes of the initial contents of the heavier elements ( $\mathrm{Ni}, \mathrm{Cr}, \mathrm{Ta})$ which can be easily analyzed. Therefore carbon appears as being responsible of these microstructures modifications having led to these new carbides zones. The increasing of the volume fractions of $\mathrm{M}_{23} \mathrm{C}_{6}$ inside the new carbides zone compared to the bulk, the shifting from $M_{23} C_{6}$ to $M_{7} C_{3}$ or the precipitation of new carbides in the matrix itself seems indicate that this region is obviously become enriched in carbon.

In order to confirm this hypothesis and to better know how many carbon is come in this zone thermodynamic calculations were performed from the locally analyzed Ni-Cr-Ta composition with test of successive values for the carbon content in the $[0 \% \mathrm{wt} \mathrm{C} ; 1.0 \% \mathrm{wt} \mathrm{C}]$ range until the measured volume fraction (converted in mass fraction) is reached. Table IV presents the results of these calculations.

It appeared always possible to reach the measured carbides volume fractions really measured on the new carbides zones in the alloys after oxidation. On the one hand it appears that the process is diffusioncontrolled and allows the local microstructure to continuously stay to the equilibrium corresponding to the local composition at each time. On the other hand, this microstructure effectively leads to know the local carbon content. The carbon contents determined by the thermodynamic calculation way are obviously higher than the initial ones, of an average of $50 \%$ of the carbon content of each alloy before oxidation test.

\section{Discussion}

This carbon enrichment of the new carbides zone was not obtained with carbon coming from the bulk. Indeed we verified that the microstructure of the whole bulk was homogeneous and also well corresponded for the same temperature to the thermodynamic stable state calculated from the initial composition. Therefore, the only possible carbon supplier is the carbideless zone which was effectively impoverished in carbon. Following this hypothesis, Table $\mathrm{V}$ presents in its first column the maximal carbon mass lost by the carbideless zone per surface unit, considering that nearly all its carbon left it. The last column contains the mass or molar percentage of this carbon which could be go in the neighbor new carbides zone. The maximal possible carbon quantity lost by the carbideless zone per surface unit increases when temperature increases. In addition more carbon is here lost when the initial carbon content is higher (Alloy B and Alloy C compared to Alloy A) while no such rule existed for the depth of the carbideless zone. The part of this carbon having participated to the carbon enrichment of the new carbide zone is of about $100 \%$ at $1000^{\circ} \mathrm{C}$ and decreases with temperature to finally fall to zero at $1200^{\circ} \mathrm{C}$.

Thus, it appears that at $1000^{\circ} \mathrm{C}$ oxidation did not only induce a diffusion of chromium and tantalum, initially present in solid solution as well as in the interdendritic carbides, from the bulk towards the oxidation 
front. But it was evidenced that, for certain conditions, carbon released by the disappearing carbides diffuses in the opposite way, towards the bulk. The progress with time of this carbon transport obviously leads to a carbon enrichment inside a more internal zone in which this enrichment promotes different possible carbides changes depending on the alloy composition. At $1100^{\circ} \mathrm{C}$ only a part of this carbon remains in the alloy in which it participates to the carbide transformations to give a new carbides zone, like for $1000^{\circ} \mathrm{C}$. The other part of the carbon either quitted the alloy (oxidized into gases) or diffused deeper in the alloy. The second hypothesis appears to be difficult to verify since the carbides existing deeper than the new carbides zone would have not sufficiently changed. It is more true at $1200^{\circ} \mathrm{C}$ for which no new carbides zone obviously exist and no microstructure change showing a carbon enrichment can be seen anywhere. Then, either carbon has totally quitted the alloy or it diffused on such a wide depth that a carbon enrichment is locally too light to be detected in the microstructure. Carbide surface analysis and thermodynamic calculations become no sufficiently efficient either to affirm that there is no other carbon enrichment deeper or to precise too little carbon content modifications.

Such phenomena were already encountered earlier for others metallic alloys after high temperature oxidation. For example, Singh et al (Ref. 11) also observed a carbideless zone growing from the extreme surface for iron-base alloys containing both aluminum and carbon. They explained that the disappearance of the initial $\mathrm{Fe}_{3} \mathrm{AlC}$ carbides took place simultaneously with a diffusion of the released carbon atoms out to the surface. Durham et al (Ref. 10) studied the dependence of the chromia-forming behavior of iron-base alloys on the coarseness of their chromium carbides. They encountered a dissolution of the finest carbides which acted as reservoirs of chromium for supplying the external chromia scale, then the growth of a carbides-depleted zone. Ennis et al (Ref. 12) also saw, for a nickel superalloy exposed to $900^{\circ} \mathrm{C}$ for a long time, the formation of a carbideless sub-surface zone. They also explained that the carbon atoms released by the dissolving carbides migrated to the center of their thin specimen to give an enhanced carbide precipitation. In addition Kaya et al (Ref. 13) saw that carburizing atmospheres induced also similar phenomena : both a coarsening and a transformation into the $\mathrm{M}_{7} \mathrm{C}_{3}$ stoechiometry for the initial $\mathrm{M}_{23} \mathrm{C}_{6}$ carbides of the Fe-Cr-Ni based HK40 alloy. They also observed a coarsening of $\mathrm{M}_{23} \mathrm{C}_{6}$ without nature changes and the precipitation of $\mathrm{M}_{7} \mathrm{C}_{3}$.

Thus we found in this work similar phenomena as previously observed for other alloys : disappearance of carbides with growth of a carbideless zone, appearance of a new zone with coarsening, stoechiometry modification or matrix precipitation of carbides, and that related to one or two types of diffusion of carbon atoms released by dissolving carbides. In this work both surface fractions of carbides and the different local carbon contents were furthermore quantitatively determined, respectively by image analysis measurements and deduced from thermodynamic calculations. This lead to precise the part which promoted the visible carbides modifications in the sub-surface of the alloy, and the part which either quitted the alloy or diffused deeper in the alloy with no noticeable changes of the microstructure.

\section{CONCLUSION}

When exposed to high temperature oxidation carbide-strengthened superalloys can encounter specific phenomena which can be potentially important for their local mechanical properties near the external surface : growth of a sub-surface zone without carbides, and for temperatures less than $1200^{\circ} \mathrm{C}$, appearance of a second zone enriched in carbon and in which the carbide system is coarsened or modified. If such phenomena were encountered earlier, a balance sheet was made in this work which lead to precise the new distribution of carbon in the whole zone affected by oxidation. Thus the mechanisms described in previous works were here found again, with a more quantitative knowledge of the new local carbon contents, not obtained using microanalysis but indirectly determined from thermodynamic calculations. Thermodynamic modeling was precisely revealed as an useful tool, complementary to more classical equipment when oxidation phenomena are studied. It allows to precise the last remaining unknown quantity that is a light element content. 


\section{ACKNOWLEDGMENTS}

The authors thank S. Michon who built the thermodynamic database used here, and the Microanalysis Common Service of the Faculty of Science of Nancy, especially J. Demange, J. Ravaux and A. Kohler.

\section{REFERENCES}

1. P. Kofstad, High Temperature Corrosion, Elsevier applied science, 1988.

2. D. J. Young, and B. Gleeson, Corrosion Science, 44, 345-357 (2002)

3. $\quad$ E. F. Bradley, Superalloys : A Technical Guide, ASM International, 1988.

4. $\quad$ C. T. Sims and W. C. Hagel, The Superalloys, John Wiley \& Sons, 1972.

5. Handbook of Chemistry and Physics, $57^{\text {th }}$ edition (1976-1977)

6. Thermo-Calc version N or Win NT: "Foundation for Computational Thermodynamics" Stockholm, Sweden, Copyright (1993, 2000)

7. SGTE: "Scientific Group Thermodata Europe" database, update 1992.

8. S. Michon, P. Berthod, L. Aranda, C. Rapin, R. Podor, and P. Steinmetz, CALPHAD, 27(3), 289-294 (2004).

9. P. Berthod, S. Michon, J. Di Martino, S. Mathieu, S. Noël, R. Podor, and C. Rapin, CALPHAD, 27(3), 279-288 (2004).

10. R. N. Durham, B. Gleeson, and D. J. Young, 50 (1/2), 139-165 (1998)

11. A. P. Singh, R. Balasubramaniam, and R. G. Baligidad, Materials Science and Engineering, A368(12), 48-55 (2004).

12. P. J. Ennis, W. J. Quadakkers, and H. Schuster, Journal de Physique IV, 3, 979-986 (1993).

13. A. A. Kaya, Materials Characterization, 49(1), 23-34 (2002). 
Table I. Chemical Compositions of the Studied Nickel-Base Alloys

\begin{tabular}{|l|c|c|c|c|}
\hline \multirow{2}{*}{ Alloys } & \multicolumn{4}{|c|}{ Compositions } \\
\cline { 2 - 5 } & $\mathbf{~ N i}$ & $\mathbf{C r}$ & $\mathbf{C}$ & Ta \\
\hline \multirow{2}{*}{ Alloy A } & Bal. & 30.9 & 0.2 & 2.0 \\
\hline Alloy B & Bal. & 31.9 & 0.4 & 2.7 \\
\hline Alloy C & Bal. & 30.6 & 0.4 & 5.4 \\
\hline
\end{tabular}

Table II. WDS analysis results obtained for the one or two types of chromium carbides seen in the subsurface microstructures of the samples ( $\%_{\mathrm{at}} \mathrm{Cr} / \%_{\mathrm{at}} \mathrm{C}$ ratio to compare to 2.33 for $\mathrm{M}_{7} \mathrm{C}_{3}$ and 3.83 for $\mathrm{M}_{23} \mathrm{C}_{6}$ )

\begin{tabular}{|c|c|c|c|c|c|c|}
\hline \multirow[t]{2}{*}{$\begin{array}{l}\text { Alloy } \\
\text { Temperature }\end{array}$} & \multicolumn{3}{|c|}{$\begin{array}{c}\mathbf{M}_{\mathbf{7}} \mathbf{C}_{\mathbf{3}} \\
\text { (average value } \pm \text { standard deviation) }\end{array}$} & \multicolumn{3}{|c|}{$\begin{array}{c}\mathbf{M}_{\mathbf{2 3}} \mathbf{C}_{\mathbf{6}} \\
\text { (average value } \pm \text { standard deviation) }\end{array}$} \\
\hline & $\%_{\mathrm{at}} \mathrm{Cr}$ & $\%_{\mathrm{at}} \mathrm{C}$ & $\%_{\mathrm{at}} \mathrm{Cr} / \%_{\mathrm{at}} \mathrm{C}$ & $\%_{\mathrm{at}} \mathrm{Cr}$ & $\%_{\mathrm{at}} \mathrm{C}$ & $\%_{\mathrm{at}} \mathrm{Cr} / \%_{\mathrm{at}} \mathrm{C}$ \\
\hline $\begin{array}{l}\text { Alloy } \mathrm{A} \quad 1200^{\circ} \mathrm{C} \\
\mathrm{M}_{7} \mathrm{C}_{3} \text { and rares } \mathrm{M}_{23} \mathrm{C}_{6}\end{array}$ & $69.0 \pm 1.9$ & $28.3 \pm 1.8$ & $2.5 \pm 0.2$ & / & l & / \\
\hline $\begin{array}{l}\text { Alloy A } 1100^{\circ} \mathrm{C} \\
\mathrm{M}_{7} \mathrm{C}_{3} \text { and } \mathrm{M}_{23} \mathrm{C}_{6}\end{array}$ & $65.3 \pm 7.5$ & $24.9 \pm 1.2$ & $2.6 \pm 0.4$ & $75.9 \pm 0.8$ & $22.3 \pm 0.8$ & $3.4 \pm 0.2$ \\
\hline $\begin{array}{l}\text { Alloy A } 1000^{\circ} \mathrm{C} \\
\mathrm{M}_{7} \mathrm{C}_{3} \text { and } \mathrm{M}_{23} \mathrm{C}_{6}\end{array}$ & I & l & / & $78.4 \pm 3.0$ & $21.8 \pm 2.7$ & $3.7 \pm 0.7$ \\
\hline $\begin{array}{l}\text { Alloy B } 1200^{\circ} \mathrm{C} \\
\qquad \mathrm{M}_{7} \mathrm{C}_{3}\end{array}$ & $66.9 \pm 0.5$ & $28.2 \pm 0.8$ & $2.4 \pm 0.1$ & / & / & / \\
\hline $\begin{array}{l}\text { Alloy B } 1100^{\circ} \mathrm{C} \\
\mathrm{M}_{7} \mathrm{C}_{3}\end{array}$ & $67.8 \pm 0.8$ & $23.0 \pm 0.1$ & $2.9 \pm 0.1$ & $74.9 \pm 0.4$ & $20.7 \pm 0.5$ & $3.6 \pm 0.1$ \\
\hline $\begin{array}{l}\text { Alloy B } 1000^{\circ} \mathrm{C} \\
\text { M7C3 and } \mathrm{M} 23 \mathrm{C} 6\end{array}$ & $67.0 \pm 0.8$ & $22.9 \pm 0.1$ & $2.9 \pm 0.1$ & $70.4 \pm 4.96$ & $18.1 \pm 0.4$ & $3.9 \pm 0.3$ \\
\hline $\begin{array}{c}\text { Alloy } \mathrm{C} \quad 1200^{\circ} \mathrm{C} \\
\mathrm{M}_{7} \mathrm{C}_{3}\end{array}$ & $69.4 \pm 0.7$ & $25.8 \pm 0.7$ & $2.0 \pm 0.1$ & / & I & / \\
\hline $\begin{array}{l}\text { Alloy } \mathrm{C} 1100^{\circ} \mathrm{C} \\
\text { rare } \mathrm{M}_{7} \mathrm{C}_{3} \text { and } \mathrm{M}_{23} \mathrm{C}_{6}\end{array}$ & $70.8 \pm 0.3$ & $20.6 \pm 0.3$ & $3.4 \pm 0.1 *$ & $79.0 \pm 0.6$ & $16.1 \pm 0.3$ & $4.9 \pm 0.1^{*}$ \\
\hline $\begin{array}{l}\text { Alloy } \mathrm{C} \quad 1000^{\circ} \mathrm{C} \\
\qquad \mathrm{M}_{23} \mathrm{C}_{6}\end{array}$ & / & I & / & $82.5 \pm 1.9$ & $21.6 \pm 0.5$ & $3.8 \pm 0.1$ \\
\hline
\end{tabular}

* : stoechiometry transformation in progress or participation of the matrix under the carbide to the WDS analysis results 
Table III. Results of metallographic examination of bulk and near surface microstructure of the three alloys after the three exposures to high temperature oxidation

\begin{tabular}{|c|c|c|c|c|}
\hline \multirow[b]{2}{*}{ Temperature } & \multicolumn{2}{|c|}{ thickness $(\mu \mathrm{m})$} & \multicolumn{2}{|c|}{$\begin{array}{l}\text { surface or volume fraction of carbides } \\
\text { in the intermediate zone } \\
\text { (and corresponding weight fractions) }\end{array}$} \\
\hline & carbideless zone & intermediate zone & $\mathbf{M}_{7} \mathbf{C}_{3}$ & $\mathrm{M}_{23} \mathrm{C}_{6}$ \\
\hline \multirow[t]{2}{*}{ Alloy A $1200^{\circ} \mathrm{C}$} & \multirow[t]{2}{*}{230} & \multirow[t]{2}{*}{ / } & l & l \\
\hline & & & \multicolumn{2}{|c|}{ bulk : $2.44 \% \mathrm{M}_{7} \mathrm{C}_{3}$} \\
\hline \multirow[t]{2}{*}{ Alloy A $1100^{\circ} \mathrm{C}$} & \multirow[t]{2}{*}{79} & \multirow[t]{2}{*}{158} & $3.39(2.66)$ & I \\
\hline & & & \multicolumn{2}{|c|}{ bulk : $\mathbf{2 . 6 6} \% \mathrm{M}_{7} \mathrm{C}_{3}$ and $\mathrm{M}_{23} \mathrm{C}_{6}$} \\
\hline \multirow[t]{2}{*}{ Alloy A $1000^{\circ} \mathrm{C}$} & \multirow[t]{2}{*}{18} & \multirow[t]{2}{*}{39} & I & $\mathbf{6 . 2 0}(4.91)$ \\
\hline & & & \multicolumn{2}{|c|}{ bulk : $\mathbf{3 . 6 8} \% \mathrm{M}_{23} \mathrm{C}_{6}$} \\
\hline \multirow{2}{*}{ Alloy B } & \multirow[t]{2}{*}{200} & \multirow[t]{2}{*}{ l } & I & I \\
\hline & & & \multicolumn{2}{|c|}{ bulk : $\mathbf{6 . 1 7} \% \mathrm{M}_{7} \mathrm{C}_{3}$} \\
\hline \multirow[t]{2}{*}{ Alloy B $1100^{\circ} \mathrm{C}$} & \multirow[t]{2}{*}{73} & \multirow[t]{2}{*}{97} & $6.33(5.03)$ & $2.45(1.95)$ \\
\hline & & & \multicolumn{2}{|c|}{ bulk: $\mathbf{7 . 0 4} \% \mathrm{M}_{7} \mathrm{C}_{3}$ and $\mathrm{M}_{23} \mathrm{C}_{6}$} \\
\hline \multirow[t]{2}{*}{ Alloy B $\quad 1000^{\circ} \mathrm{C}$} & \multirow[t]{2}{*}{40} & \multirow[t]{2}{*}{64} & $5.95(4.75)$ & $\mathbf{4 . 5 0}(3.60)$ \\
\hline & & & \multicolumn{2}{|c|}{ bulk : $\mathbf{7 . 0 9} \% \mathrm{M}_{23} \mathrm{C}_{6}$} \\
\hline \multirow[t]{2}{*}{ Alloy $\mathrm{C} \quad 1200^{\circ} \mathrm{C}$} & \multirow[t]{2}{*}{170} & \multirow[t]{2}{*}{ I } & 1 & I \\
\hline & & & \multicolumn{2}{|c|}{ bulk : $\mathbf{3 . 7 1} \% \mathrm{M}_{7} \mathrm{C}_{3}$ and $\mathbf{2 . 9 3} \% \mathrm{TaC}$} \\
\hline \multirow[t]{2}{*}{ Alloy $\mathrm{C} \quad 1100^{\circ} \mathrm{C}$} & \multirow[t]{2}{*}{85} & \multirow[t]{2}{*}{85} & $\mathbf{1 0 . 0 0}(7.97)$ & I \\
\hline & & & \multicolumn{2}{|c|}{ bulk : $\mathbf{7 . 0 0} \% \mathrm{M}_{23} \mathrm{C}_{6}$ and $\mathbf{3 . 4 8} \% \mathrm{TaC}$} \\
\hline \multirow[t]{2}{*}{ Alloy $\mathrm{C} \quad 1000^{\circ} \mathrm{C}$} & \multirow[t]{2}{*}{24} & 48 & I & $12.79(10.28)$ \\
\hline & & & bulk : 7.74 & $\mathrm{~d} \mathbf{2 . 1 2} \% \mathrm{TaC}$ \\
\hline
\end{tabular}


Table IV. Carbon contents of the C-enriched zone determined by calculation; carbides natures and mass fractions calculated with these carbon contents

\begin{tabular}{|c|c|c|}
\hline Temperature & $\begin{array}{l}\text { carbon content in the } \\
\text { C-enriched zone } \\
\text { (weight \%) }\end{array}$ & $\begin{array}{l}\text { theoric carbides for } \\
\text { this calculated \%C } \\
\text { (weight fraction \%) }\end{array}$ \\
\hline Alloy A $1200^{\circ} \mathrm{C}$ & I & I \\
\hline Alloy A $\quad 1100^{\circ} \mathrm{C}$ & 0.260 & $2.66 \%$ wt $\mathrm{M}_{7} \mathrm{C}_{3}$ \\
\hline Alloy A $\quad 1000^{\circ} \mathrm{C}$ & 0.289 & $4.91 \%$ wt $\mathrm{M}_{23} \mathrm{C}_{6}$ \\
\hline Alloy B $\quad 1200^{\circ} \mathrm{C}$ & I & I \\
\hline Alloy B $\quad 1100^{\circ} \mathrm{C}$ & 0.472 & $\begin{array}{c}5.03 \% \text { wt } \mathrm{M}_{7} \mathrm{C}_{3} \\
0.00 \% \text { wt M23C6 }\end{array}$ \\
\hline Alloy B $\quad 1000^{\circ} \mathrm{C}$ & 0.646 & $\begin{array}{l}4.75 \% \text { wt } \mathrm{M}_{7} \mathrm{C}_{3} \\
3.64 \% \text { wt } \mathrm{M}_{23} \mathrm{C}_{6}\end{array}$ \\
\hline Alloy C $\quad 1200^{\circ} \mathrm{C}$ & I & 1 \\
\hline Alloy C $\quad 1100^{\circ} \mathrm{C}$ & 0.737 & $7.97 \%$ wt $\mathrm{M}_{7} \mathrm{C}_{3}$ \\
\hline Alloy C $\quad 1000^{\circ} \mathrm{C}$ & 0.592 & $10.28 \%$ wt $\mathrm{M}_{23} \mathrm{C}_{6}$ \\
\hline
\end{tabular}

Table V. Amount of the carbon lost by the carbideless zone and part of this carbon used for the carbon enrichment of the new carbides zone

\begin{tabular}{|l|c|c|}
\hline \begin{tabular}{|l|} 
Alloy \\
Temperature
\end{tabular} & $\begin{array}{c}\text { maximal mass lost by } \\
\text { the carbideless zone } \\
\left(\mathrm{mg} / \mathrm{cm}^{2}\right)\end{array}$ & $\begin{array}{c}\text { part kept by the C- } \\
\text { enriched zone } \\
(\%)\end{array}$ \\
\hline Alloy A $1200^{\circ} \mathrm{C}$ & 0.409 & 0 \\
\hline Alloy A $1100^{\circ} \mathrm{C}$ & 0.141 & 60 \\
\hline Alloy A $1000^{\circ} \mathrm{C}$ & 0.032 & 0 \\
\hline Alloy B $1200^{\circ} \mathrm{C}$ & 0.712 & 24 \\
\hline Alloy B $1100^{\circ} \mathrm{C}$ & 0.259 & 98 \\
\hline Alloy B $1000^{\circ} \mathrm{C}$ & 0.142 & 0 \\
\hline Alloy C $1200^{\circ} \mathrm{C}$ & 0.605 & 84 \\
\hline Alloy C $1100^{\circ} \mathrm{C}$ & 0.303 & 96 \\
\hline Alloy C $1000^{\circ} \mathrm{C}$ & 0.085 & \\
\hline
\end{tabular}




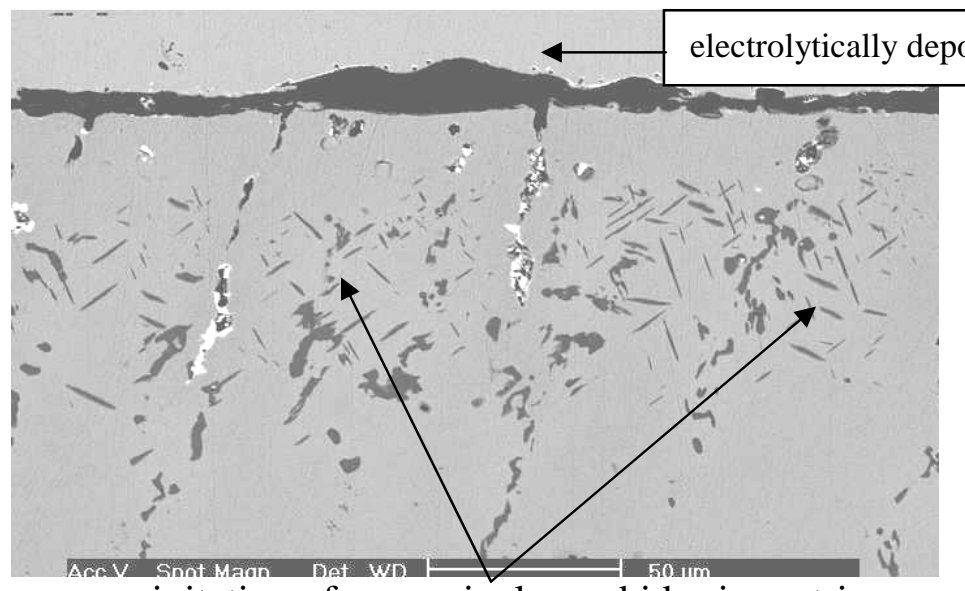

precipitation of new acicular carbides in matrix

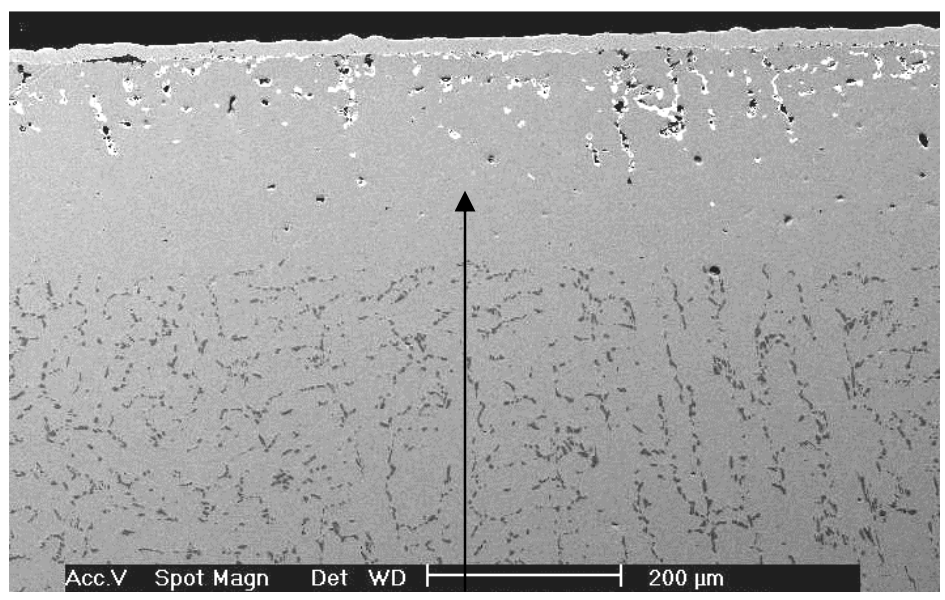

disappearance of carbides

\section{Fig. 1.}

Several possible phenomena occurring during the high temperature oxidation of carbide-strengthened superalloys

(here different nickel-base cast superalloys) 

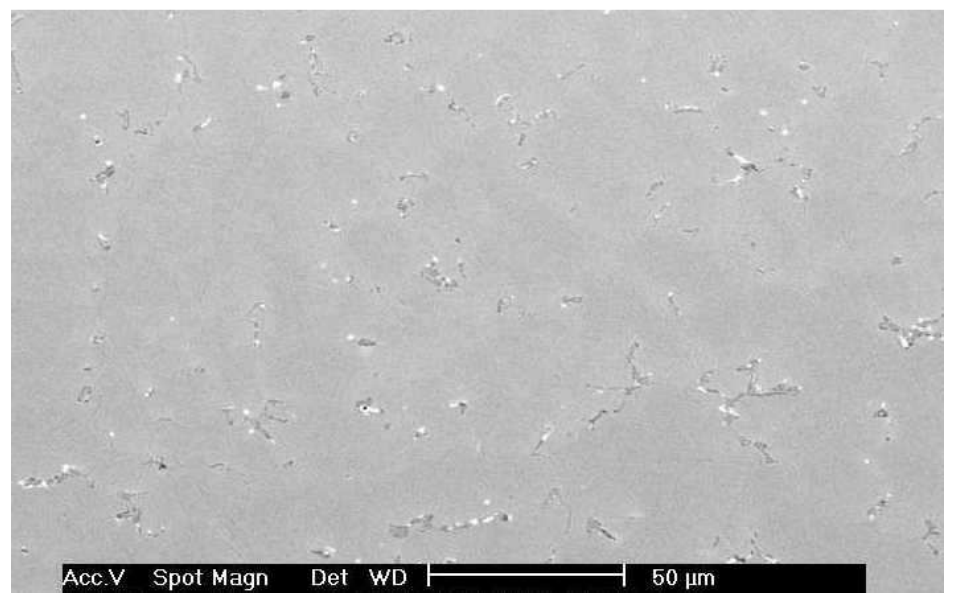

Det WD

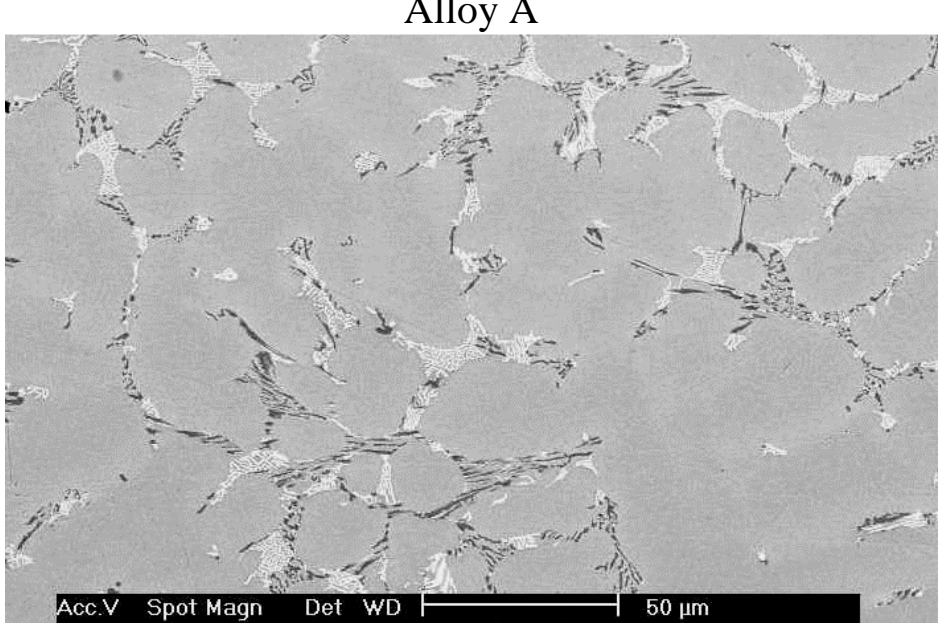

Alloy C

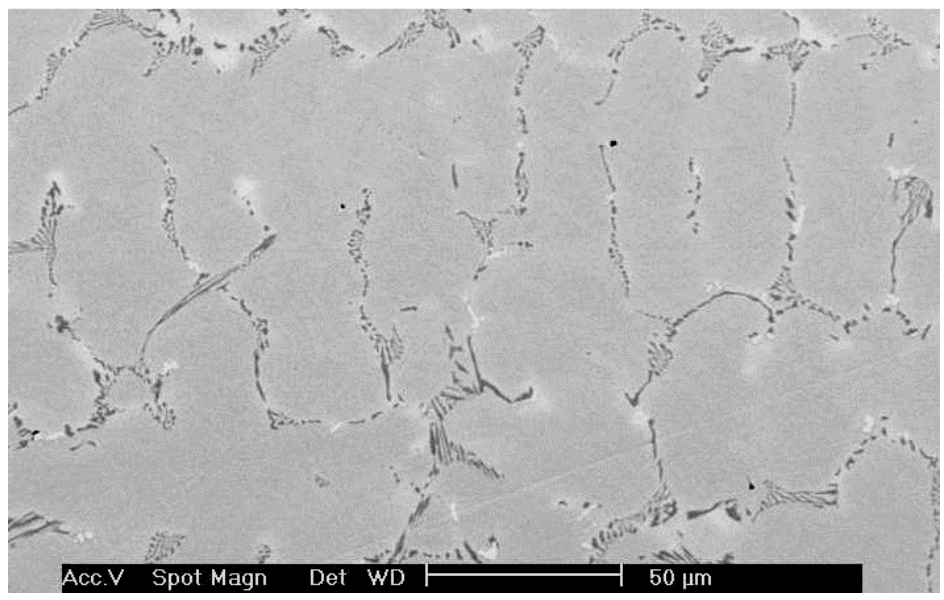

Alloy B

Fig. 2.

As-cast microstructures of the three alloys 


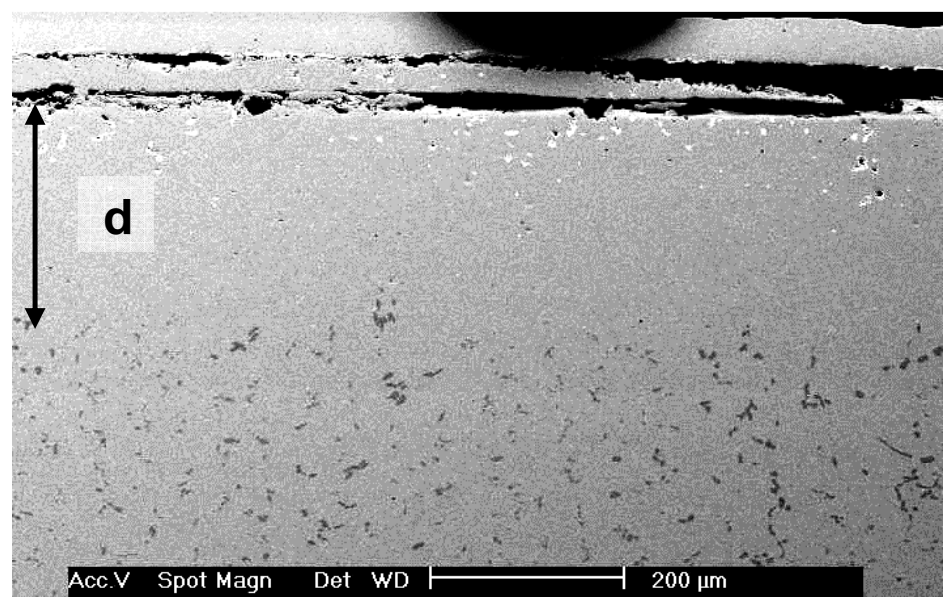

Alloy A oxidized for 100 hours

at $1200^{\circ} \mathrm{C}$

$\mathrm{d}=230 \mu \mathrm{m}$

(carbideless zone)

no new carbides
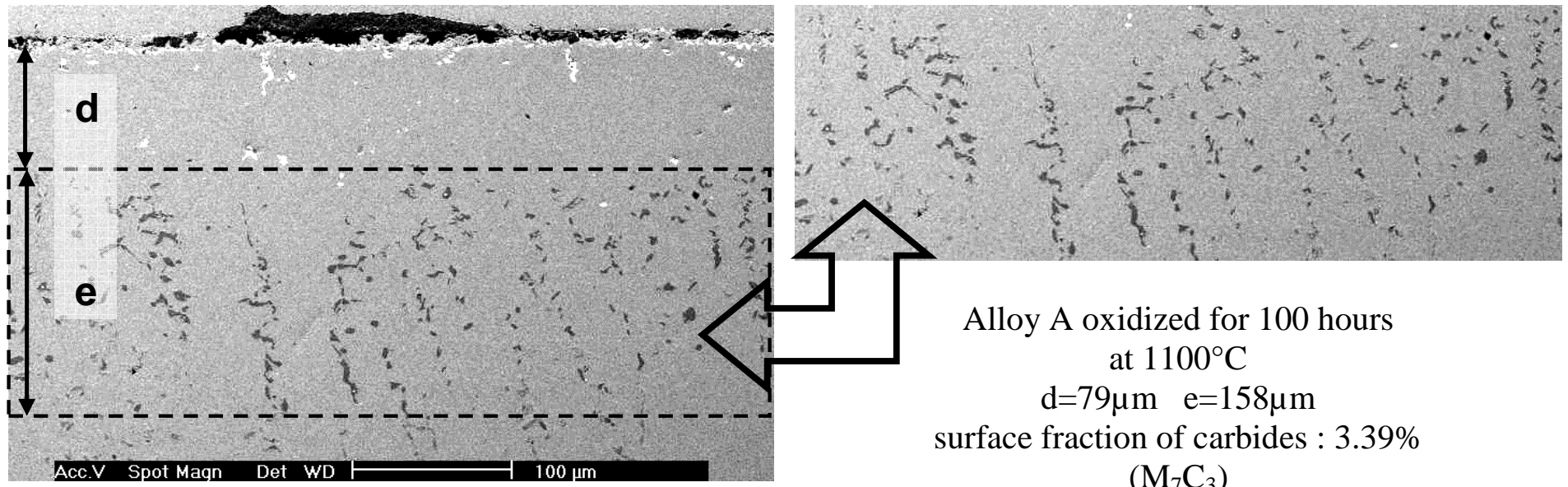

Alloy A oxidized for 100 hours

at $1100^{\circ} \mathrm{C}$

$$
\mathrm{d}=79 \mu \mathrm{m} \quad \mathrm{e}=158 \mu \mathrm{m}
$$

surface fraction of carbides : $3.39 \%$

$\left(\mathrm{M}_{7} \mathrm{C}_{3}\right)$

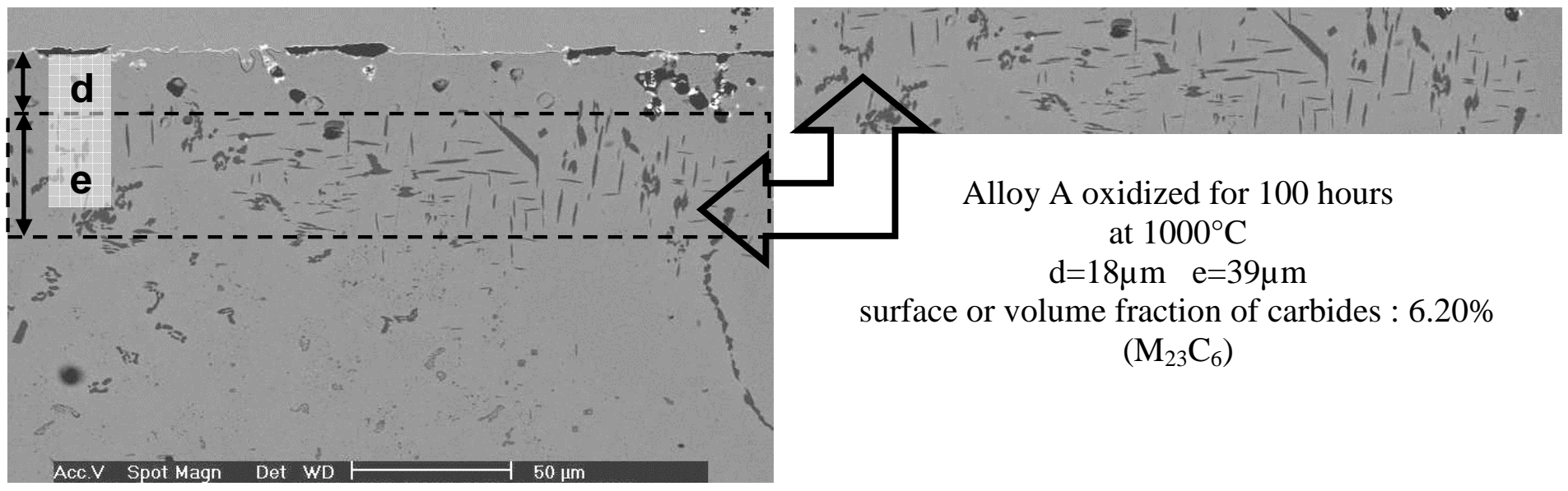

Fig. 3. Quantification of surface deterioration by oxidation for Alloy A 


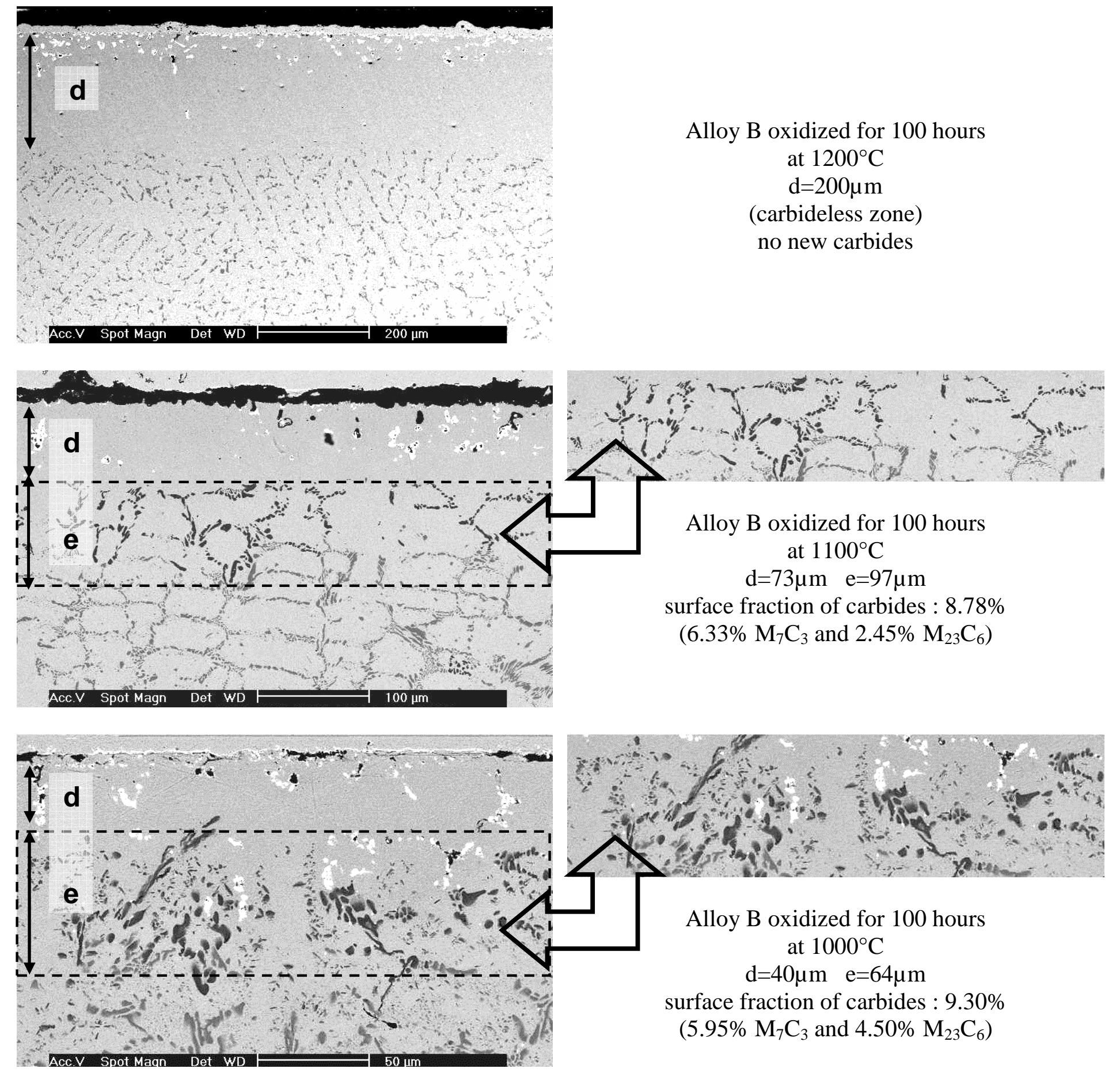

Fig. 4. Quantification of surface deterioration by oxidation for Alloy B 


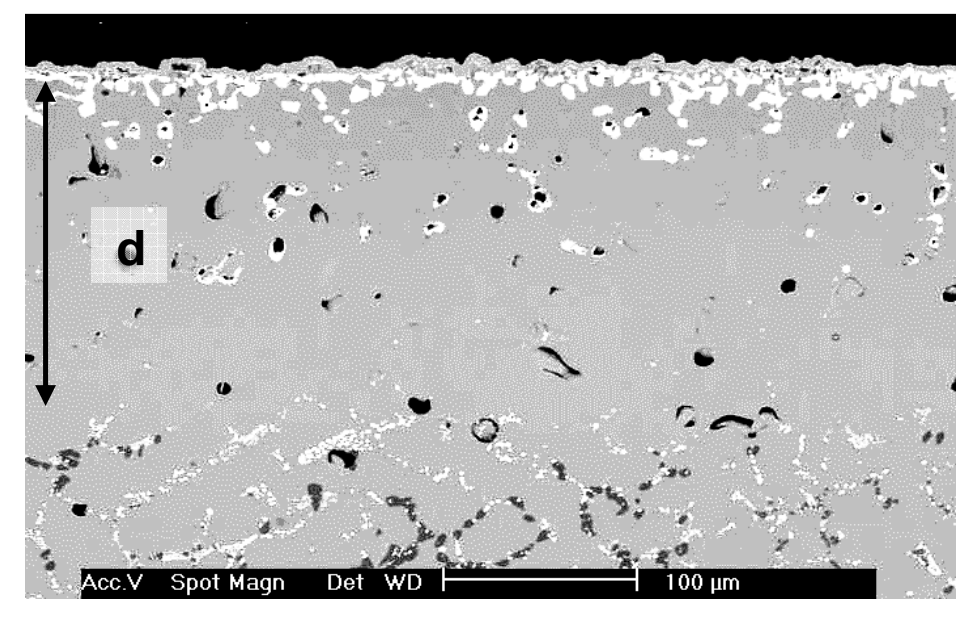

Alloy C oxidized for 100 hours

at $1200^{\circ} \mathrm{C}$

$\mathrm{d}=170 \mu \mathrm{m}$

(carbideless zone)

no new carbides

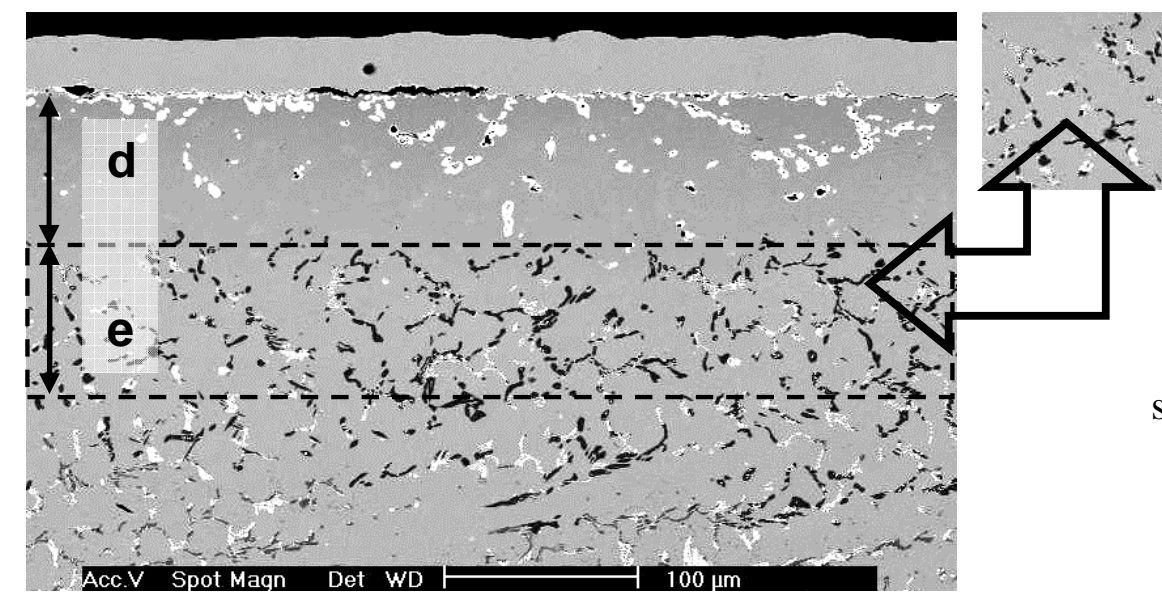

Alloy C oxidised for 100 hours at $1100^{\circ} \mathrm{C}$ $\mathrm{d}=85 \mu \mathrm{m} \quad \mathrm{e}=85 \mu \mathrm{m}$

surface fraction of carbides : $10.0 \%$ $\left(10.0 \% \mathrm{M}_{7} \mathrm{C}_{3}\right)$

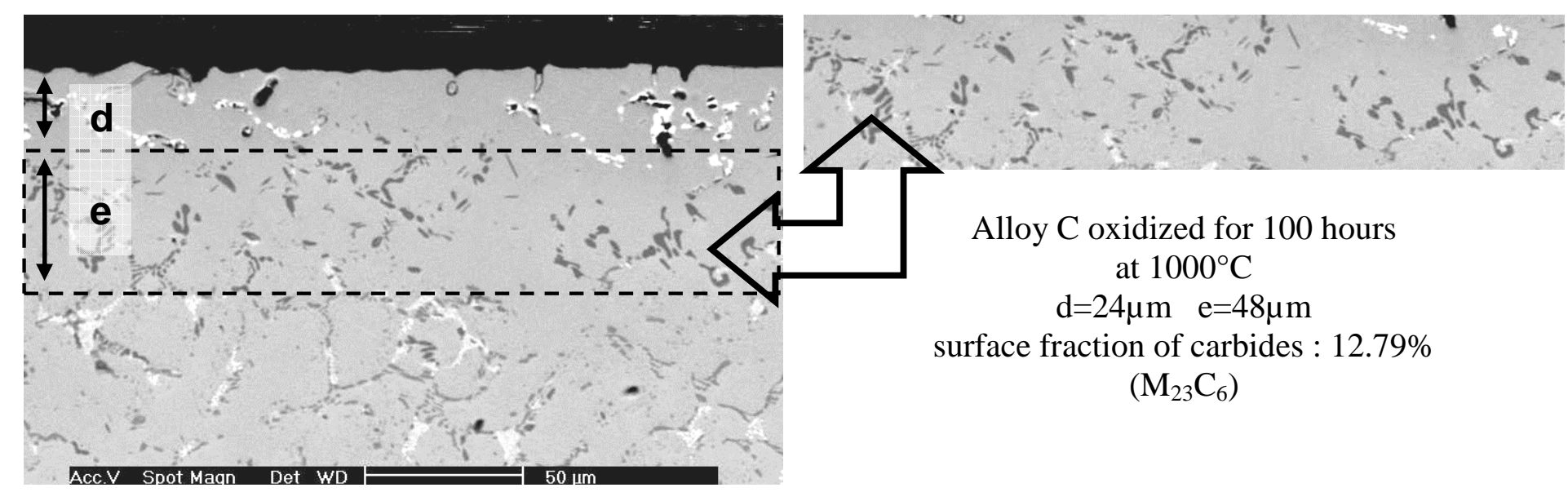

Fig. 5. Quantification of surface deterioration by oxidation for Alloy $\mathrm{C}$ 


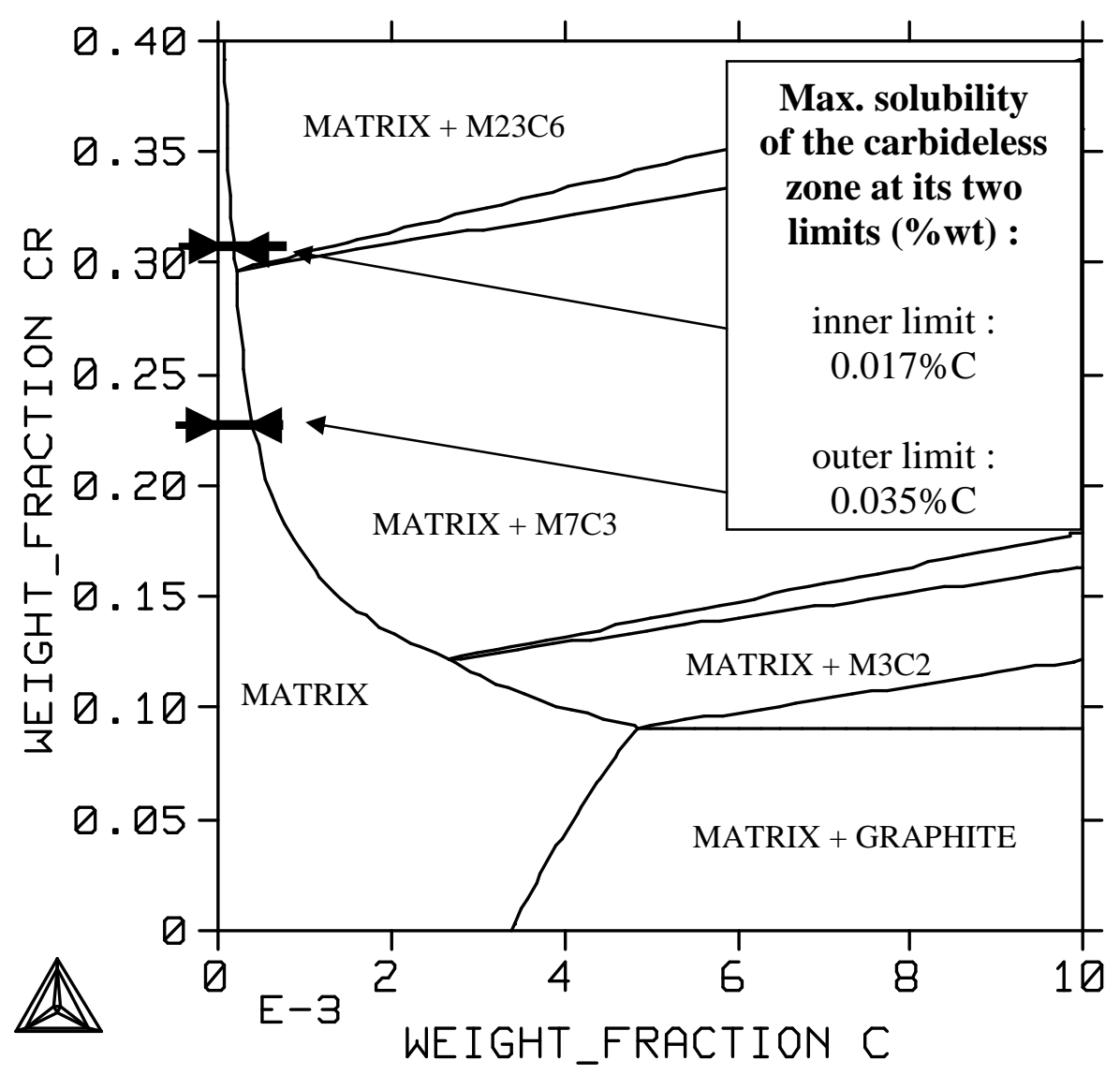

Fig.6. Isothermal cut of phase diagram for Alloy A at $1100^{\circ} \mathrm{C}$ 